ISSN: 2302-8556

E-Jurnal Akuntansi Universitas Udayana

Vol.24.1.Juli (2018): 1-29

DOI: https://doi.org/10.24843/EJA.2018.v24.i01.p01

\title{
Pengaruh Profitabilitas, Leverage, dan Modal Kerja Pada Nilai Perusahaan dengan CSR Sebagai Variabel Intervening
}

\author{
I Gusti Ngurah Yoga Dimas Atmaja ${ }^{1}$ \\ Ida Bagus Putra Astika ${ }^{2}$
}

${ }^{1}$ Fakultas Ekonomi dan Bisnis Universitas Udayana (Unud), Bali, Indonesia
email: yogaatmaja@rocketmail.com/ Telp : 087861678977
${ }^{2}$ Fakultas Ekonomi dan Bisnis Universitas Udayana (Unud), Bali, Indonesia

\begin{abstract}
ABSTRAK
Perusahaan merupakan sekelompok orang yang tergabung dalam suatu organisasi yang bekerja untuk mencapai tujuan tertentu. Salah satu tujuan perusahaan yang paling mendasar adalah untuk memperoleh keuntungan atau laba yang maksimal dari kegiatan usaha yang dilakukan perusahaan. Tujuan didirikannya suatu perusahaan tidak hanya sekedar untuk meraih laba sebesar-besarnya, tetapi juga bertujuan untuk meningkatkan kemakmuran pihak-pihak yang berkaitan dengan kegiatan usaha perusahaan, seperti shareholders dan stakeholders sehingga nilai perusahaan tersebut meningkat. Tujuan Penelitian ini adalah untuk mengetahui pengaruh profitabilitas, leverage, dan modal kerja pada nilai perusahaan dengan CSR sebagai variabel intervening. Penelitian ini dilakukan di perusahaan consumer goods yang terdaftar di BEI (Bursa Efek Indonesia) periode tahun 2013-2015. Jumlah sampel yang diambil sebanyak 75 perusahaan, dengan metode purposive sampling. Pengumpulan data dilakukan dengan mengunduh laporan tahunan perusahaan. Teknik analisis data yang digunakan antara lain analisis regresi linear berganda yang membutuhkan statistik deskriprif, uji asumsi klasik, path analysis, dan uji sobel. Berdasarkan hasil path analysis dan uji sobel ditemukan bahwa profitabilitas dan leverage tidak berpengaruh pada CSR, sedangkan modal kerja berpengaruh positif pada CSR. Profitabilitas berpengaruh positif pada nilai perusahaan, sedangkan variabel leverage dan modal kerja tidak berpengaruh pada nilai perusahaan. CSR tidak dapat memediasi pengaruh profitabilitas, leverage, dan modal kerja pada nilai perusahaan.
\end{abstract}

Kata Kunci: profitabilitas, leverage, modal kerja, CSR, nilai perusahaan

\begin{abstract}
Companies are a group of people who are members of an organization that works to achieve certain goals. One of the company's most fundamental goals is to gain maximum profit or profit from its business activities. The purpose of establishment of a company not only to achieve maximum profit, but also aims to improve the prosperity of parties related to corporate activities, such as shareholders and stakeholders so that the value of the company increases. The purpose of this study is to determine the effect of profitability, leverage, and working capital on corporate value with CSR as intervening variable. This research is conducted in consumer goods company listed in Indonesia Stock Exchange (IDX) period 2013-2015 period. The number of samples taken as many as 75 companies, with purposive sampling method. Data collection is done by downloading the company's annual report. Analytical techniques used include regression analysis that requires descriptive statistics, classical assumption test, path analysis, and test sobel. Pursuant to result of path analysis and sobel test found that profitability and leverage not have an effect on CSR, while working capital have positive effect on CSR. Profitability affects positively on firm value, while leverage and working capital have
\end{abstract}


no effect on firm value. CSR can not mediate the effect of profitability, leverage, and working capital on firm value.

Keywords: profitability, leverage, working capital, CSR, corporate value

\section{PENDAHULUAN}

Perusahaan merupakan sekelompok orang yang tergabung dalam suatu organisasi yang bekerja untuk mencapai tujuan tertentu. Salah satu tujuan perusahaan yang paling mendasar adalah untuk memperoleh keuntungan atau laba yang maksimal dari kegiatan usahanya. Berbagai tekanan yang muncul di masyarakat membuat perusahaan kini bukan hanya bertanggungjawab semata-mata kepada pemegang saham dan kreditur saja, namun telah diharuskan bertanggungjawab kepada masyarakat luas. Hal tersebut menggeser pemikiran terhadap tanggungjawab pengelolaan perusahaan yang semula hanya kepada shareholders (pemilik/pemegang saham) kini menjadi kepada stakeholders (pemilik, karyawan, pemerintah dan masyarakat luas).

Kusumajaya (2011) menyatakan nilai perusahaan sangat penting karena mencerminkan kinerja perusahaan yang dapat mempengaruhi persepsi investor terhadap perusahaan. Peningkatan nilai perusahaan dapat memberikan sinyal positif kepada investor untuk berinvestasi pada suatu perusahaan. Nilai perusahaan pada dasarnya dapat diukur melalui beberapa aspek, salah satunya adalah dengan harga pasar saham perusahaan karena harga pasar saham perusahaan mencerminkan penilaian investor secara keseluruhan atas setiap ekuitas yang dimiliki. Harga pasar saham menunjukkan penilaian sentral dari seluruh pelaku pasar, harga pasar saham 
ISSN: 2302-8556

E-Jurnal Akuntansi Universitas Udayana

Vol.23.3.Juli (2018): 1-29

bertindak sebagai barometer kinerja manajemen perusahaan. Perusahaan luar masuk ke pasar dalam negeri mengakibatkan perusahaan dalam negeri harus memperbaiki value dan performance untuk dapat mengatasi adanya persaingan yang kuat (Melia, 2008).

Pengelolaan yang dulunya shareholders-focused ke stakeholders-focused menyebabkan perusahaan mengadopsi konsep triple bottom line. Konsep triple bottom line merupakan konsep pengukuran kinerja perusahaan dengan memasukkan tidak hanya ukuran kinerja ekonomis berupa perolehan profit, tapi juga ukuran kepedulian sosial dan pelestarian lingkungan. Konsep ini memasukkan tiga ukuran kinerja sekaligus yaitu ekonomi, lingkungan, dan sosial. Konsep triple bottom line mengimplikasikan bahwa perusahaan harus lebih mengutamakan kepentingan stakeholders dari pada kepentingan shareholders (Pebriana, 2012).

Fenomena naik turunnya harga saham menjadi isu yang berkaitan dengan nilai perusahaan. Rata-rata nilai perusahaan consumer goods mengalami kenaikan dan penurunan selama periode 2011-2015, pada tahun 2011 sebesar 4.88, tahun 2012 sebesar 7.05, tahun 2013 sebesar 6.44, dan tahun 2014 sebesar 7.61. Rata-rata nilai perusahaan mengalami pasang surut dari tahun ke tahun, tahun 2011-2012 mengalami kenaikan, tahun 2012-2013 mengalami penurunan dan tahun 2013-2014 mengalami kenaikan. Perbandingan rata-rata nilai perusahaan tahun 2011 dengan tahun 2014 mengalami kenaikan sebesar 2.73 .

Perusahaan barang konsumen (consumer goods) adalah perusahaan yang menyediakan barang yang banyak digunakan oleh konsumen/masyarakat. Oleh 
I G. N. Yoga Dimas Atmaja dan Ida Bagus Putra Astika. Pengaruh ...

karena itu, perusahaan consumer goods adalah perusahaan yang sangat rentan dengan isu lingkungan karena akan berdampak besar pada masyarakat sebagai stakeholders. Sejalan dengan itu, pengungkapan CSR merupakan program yang bertujuan memberikan pelayanan yang tidak hanya mencari keuntungan saja, tetapi lebih mementingkan aspek lingkungan. Di Indonesia sendiri sudah banyak perusahaanperusahaan yang dengan bangga mengatakan produk yang dikembangkannya merupakan produk ramah lingkungan sebagai apresiasi kepedulian sosialnya terhadap masyarakat dan lingkungan. Tupperware misalnya, dengan gencarnya melakukan publikasi atas konsepnya ini melalui beberapa media pemasaran. Pabrik deterjen saat ini juga mempergunakan kertas yang bisa didaur ulang sebagai pembungkus kemasannya.

Permasalahan tentang Corporate Social Responsibility (CSR) di Indonesia diatur dalam Pasal 74 ayat 1 Undang-Undang No.40 Tahun 2007 tentang Perseroan Terbatas bahwa perseroan yang menjalankan kegiatan usahanya di bidang dan/atau berkaitan dengan sumber daya alam wajib melaksanakan tanggungjawab sosial dan lingkungan. Selain wajib melaksanakan tanggung jawab sosial dan lingkungan perusahaan juga harus melakukan pengungkapan tanggung jawab sosial atau sering disebut Corporate Social Responsibility Disclosure (CSRD). Hal ini juga diatur dalam Pasal 66 ayat 2 huruf (c) Undang-Undang No. 40 Tahun 2007 bahwa perusahaan harus memuat laporan pelaksanaan tanggung jawab sosial dan lingkungan. Tanggungjawab sosial juga diatur dalam Pasal 15 huruf (b) UndangUndang No. 25 Tahun 2007 tentang Penanaman Modal berkewajiban melaksanakan 
ISSN: 2302-8556

E-Jurnal Akuntansi Universitas Udayana

Vol.23.3.Juli (2018): 1-29

tanggung jawab sosial perusahaan. Pengungkapan CSR yang diwajibkan tersebut membuat banyak perusahaan beberapa tahun terakhir ini mulai melakukan penerapan CSR sebagai salah satu bentuk investasi demi keberlangsungan dan pertumbuhan perusahaan mereka, selain itu tentu berdampak pada peningkatan nilai perusahaanya.

Susilawati (2012) menyatakan profitabilitas merupakan kemampuan perusahaan dalam menghasilkan laba melalui semua kemampuan dan sumber daya yang ada seperti kegiatan penjualan, kas, modal, jumlah karyawan, jumlah cabang, dan lain sebagainya. Tingginya profitabilitas perusahaan dapat memengaruhi nilai perusahaan dan itu tergantung dari persepsi investor terhadap peningkatan profitabilitas perusahaan. Maria (2013) menyatakan laba merupakan elemen dalam menciptakan nilai perusahaan karena penilaian prestasi perusahaan dilihat dari kemampuan perusahaan tersebut dalam menghasilkan laba. Kemampuan perusahaan dalam menghasilkan laba dapat diukur dengan indikator Return On Asset (ROA). ROA merupakan suatu rasio dalam mengukur kemampuan seluruh modal dalam mengahsilkan laba bagi perusahaan. ROA yang tinggi mencerminkan perusahaan dalam keadaan yang bagus yang selanjutkan akan membuat investor tertarik dalam melakukan invstasi. Ju Chen dan Yu Chen (2011) menyatakan bahwa profitabilitas berpengaruh pada nilai perusahaan. Penelitian yang dilakukan oleh Irma (2014) dan Wahyudi (2012) memperkuat penelitian Li-Ju dan Shun-Yu dengan menyatakan bahwa profitabilitas yang diproksikan dengan Return On Assets berpengaruh pada nilai perusahaan sehingga ketika laba perusahaan naik maka nilai perusahaan akan ikut naik. 
Kinerja hutang dalam rangka meningkatkan keuntungan atau likuidasi dapat dinilai dengan pengukuran leverage perusahaan. Leverage merupakan pengukuran besarnya aset yang dibiayai dengan hutang. Sejalan dengan hal tersebut penelitian yang dilakukan oleh Ayu (2013) menemukan bahwa leverage berpengaruh positif signifikan pada nilai perusahaan. Sedangkan Mahendra (2011) berpendapat bahwa leverage berpengaruh negatif dan tidak signifikan pada nilai perusahaan, Li-Ju dan Shun-Yu (2011) serta Sujoko dan Soebiantoro (2007) membuktikan leverage signifikan berpengaruh negatif pada nilai perusahaan.

Modal kerja merupakan aspek yang paling penting bagi tiap perusahaan karena modal kerja merupakan faktor penentu berjalannya kegiatan operasional dalam jangka pendek dalam perusahaan. Kegiatan operasional tersebut berpengaruh pada pendapatan yang diperoleh perusahaan. Perusahaan yang mampu menghasilkan nilai tambah atau keuntungan yang sustainable (berkelanjutan) adalah perusahaan yang mampu memanfaatkan modal kerjanya secara efektif dan efisien. Kesalahan atau tidak efektifnya pengelolaan modal kerja bisa menyebabkan menurunnya performa operasional perusahaan. Hal ini berdampak pula pada peningkatan atau penurunan nilai perusahaan yang dapat memberikan sinyal pada investor. Sabri (2012) dalam penelitiannya menyatakan tidak ada hubungan yang signifikan antara modal kerja pada nilai perusahaan. Lai (2012) menyatakan hubungan negatif antara modal kerja dengan nilai perusahaan. Hal itu disebabkan tidak konstannya modal yang disediakan perusahaan. Penelitian yang dilakukan Nurjanah, Suhadak, dan 
ISSN: 2302-8556

E-Jurnal Akuntansi Universitas Udayana

Vol.23.3.Juli (2018): 1-29

Kumadji (2014) menyatakan sebaliknya modal kerja berpengaruh signifikan terhadap nilai perusahaan.

Sejalan dengan teori keagenan yang bertujuan untuk mengurangi adanya asimetris informasi antara principal dengan agent, maka manajer harus dapat memaksimalkan keuntungan dan dapat mengungkapkan tanggung jawab sosial dari perusahaan sehingga investor akan tetap berinvestasi di perusahaan tersebut dan perusahaan akan dipandang baik oleh pihak internal dan eksternal. Hubungan antara profitabilitas perusahaan dengan CSR telah menjadi postulat (anggapan dasar) untuk mencerminkan pandangan bahwa reaksi sosial memerlukan gaya manajerial. Semakin tinggi tingkat profitabilitas perusahaan, maka semakin besar tingkat pengungkapan CSR yang dilakukan oleh perusahaan (Bowman \& Haire, 1976 dan Preston, 1978, Hackston \& Milne, 1996 dalam Anggraini, 2006). Indraswari dan Ida (2014) juga menyatakan hasil yang sejalan yaitu profitabilitas memiliki hubungan positif pada tingkat pengungkapan CSR.

$\mathrm{H}_{1} \quad$ : Profitabilitas berpengaruh positif pada CSR.

Sesuai dengan teori keagenan, dimana dalam teori keagenan terjadi sebuah perjanjian berupa kontrak antara principal dengan agent. Perusahaan yang memiliki tingkat rasio leverage yang tinggi cenderung akan mengurangi biaya-biaya dalam operasionalnya dan kemungkinan perusahaan melakukan pelanggaran perjanjian hutang. Perusahaan dengan tingkat leverage yang tinggi akan mengurangi tingkat pengungkapan CSR yang dilakukannya agar tidak menjadi sorotan para debtholders (Utami dan Sawitri, 2011). Belkaoui dan Karpik (1989) dalam Sembiring (2003) 
menyatakan bahwa semakin tinggi tingkat rasio leverage, maka semakin besar kemungkinan perusahaan akan melakukan pelanggaran perjanjian hutang, sehingga perusahaan pun akan berusaha untuk melaporkan laba sekarang lebih tinggi. Agar laba yang dilaporkan tinggi, maka manajer harus mengurangi biaya-biaya, termasuk biaya untuk mengungkapkan informasi sosial. Hasil penelitian Belkaoui dan Karpik (1989) dalam Sembiring (2003) juga menunjukkan bahwa leverage berpengaruh negatif pada CSR. Nur dan Priantinah (2012) dalam penelitiannya juga menemukan bahwa leverage berpengaruh negatif pada CSR.

$\mathrm{H}_{2} \quad$ : Leverage berpengaruh negatif pada CSR.

Tujuan dari teori sinyal adalah untuk mengurangi adanya asimetris informasi dari perusahaan kepada pihak eksternal. Pengungkapan CSR adalah salah satu cara dari perusahaan untuk menyampaikan informasi tersebut. Modal kerja yang cukup dan efektif akan meningkatkan nilai perusahaan, sehingga nilai perusahaan yang baik terkait dengan adanya pengungkapan CSR akan memberikan sinyal yang positif kepada pihak eksternal. Gatsi dan Ameyibor (2016) menyatakan bahwa modal kerja memiliki hubungan yang tidak signifikan positif terhadap CSR. Ofori, Nyuur, dan Darko (2014) pada penelitiannya menyatakan adanya hubungan positif modal kerja terhadap pengungkapan CSR. Goss dan Roberts (2009) menyatakan sebaliknya bahwa tidak ada hubungan antara modal kerja dan CSR. Perusahaan yang memiliki dan mampu mengelola modal kerja yang baik maka dapat menutupi kebutuhan jangka pendek perusahaan dengan lancar, sehingga perusahaan kemungkinan dapat mengungkapkan CSR dari hasil usaha atau labanya. 
ISSN: 2302-8556

E-Jurnal Akuntansi Universitas Udayana

Vol.23.3.Juli (2018): 1-29

$\mathrm{H}_{3}$ : Modal kerja berpengaruh positif pada CSR.

Teori sinyal menjelaskan cara perusahaan dalam menyampaikan informasi yang baik kepada calon investor agar perusahaan tersebut lebih baik dibandingkan dengan perusahaan lainnya. Salah satu sinyal yang digunakan oleh investor dalam menentukan investasi adalah laporan keuangan perusahaan. Dalam laporan keuangan tersebut terdapat rasio-rasio keuangan yang dijadikan pedoman oleh investor dalam berinvestasi. Salah satunya adalah profitabilitas perusahaan yang dalam penelitian ini diproksikan melalui Return On Assets (ROA). Return On Asset (ROA) merupakan rasio yang diperhatikan investor dalam menganalisis laporan kinerja keuangan perusahaan. Susianti (2013) berpendapat nilai ROA yang tinggi merupakan sinyal positif bagi investor bahwa perusahaan dalam kondisi yang menguntungkan. Tingginya rasio ROA akan menjadi daya tarik investor dalam berinvestasi pada perusahaan tersebut sehingga akan manaikkan nilai perusahaan. Penelitian mengenai profitabilitas terhadap nilai perusahaan dilakukan oleh Li-Ju dan Shun-Yu (2011). Penelitian tersebut menunjukkan bahwa profitabilitas berpengaruh terhadap nilai perusahaan. Penelitian yang dilakukan oleh Irma (2014) dan Wahyudi (2012) memperkuat penelitian Li-Ju dan Shun-Yu dengan menyatakan bahwa profitabilitas yang diproksikan dengan Return On Assets berpengaruh terhadap nilai perusahaan sehingga ketika laba perusahaan naik maka nilai perusahaan akan ikut naik.

$\mathrm{H}_{4} \quad$ : Profitabilitas berpengaruh positif pada nilai perusahaan.

Teori keagenan yang dilandasi oleh sebuah kontrak dapat meminimalisir adanya konflik agensi. Struktur hutang atau leverage merupakan gambaran mengenai 
I G. N. Yoga Dimas Atmaja dan Ida Bagus Putra Astika. Pengaruh ...

besar atau kecilnya pemakaian hutang oleh suatu perusahaan yang digunakan untuk membiayai aktivitas operasionalnya. Leverage yang semakin tinggi akan menimbulkan masalah keuangan, sehingga nilai perusahaan pun menurun (Sujoko dan Soebiantoro, 2007). Semakin tinggi tingkat leverage suatu perusahaan, maka semakin besar peluang perusahaan mengalami pailit, sehingga resiko kreditur pun akan meningkat, dan dapat menimbulkan masalah keagenan (Li-Ju dan Shun-Yu, 2011). Kesimpulannya rasio leverage yang tinggi menyebabkan turunnya nilai perusahaan (Weston dan Copeland, 1992 dalam Rahayu dan Asandimitra, 2014). Penelitian yang dilakukan oleh Li-Ju dan Shun-Yu (2011) dan Sujoko dan Soebiantoro (2007) membuktikan leverage signifikan berpengaruh negatif pada nilai perusahaan.

$\mathrm{H}_{5} \quad$ : Leverage berpengaruh negatif pada nilai perusahaan.

Teori keagenan menyatakan principal dalam hubungannya dengan agent dilandasi oleh sebuah kontrak. Kontrak tersebut mendelegasikan keinginan principal kepada agent, dimana agent menjalankan pendelegasian tersebut salah satunya adalah menjalankan operasional perusahaan. Agent dalam menjalankan operasional perusahaan yaitu salah satunya pengelolaan modal kerja. Modal kerja yang cukup dan dapat digunakan oleh pihak agent dengan baik akan menghasilkan keuntungan bagi perusahaan sehingga berdampak kepada peningkatan nilai perusahaan. Sabri (2012) dalam penelitiannya menyatakan tidak ada hubungan yang signifikan antara modal kerja pada nilai perusahaan. Hal itu disebabkan tidak konstannya modal yang disediakan perusahaan. Lai (2012) menyatakan hubungan negatif antara modal kerja 
ISSN: 2302-8556

E-Jurnal Akuntansi Universitas Udayana

Vol.23.3.Juli (2018): 1-29

dengan nilai perusahaan. Penelitian yang dilakukan Nurjanah, Suhadak, dan Kumadji (2014) menyatakan sebaliknya modal kerja berpengaruh signifikan terhadap nilai perusahaan.

$\mathrm{H}_{6} \quad$ : Modal kerja berpengaruh negatif pada nilai perusahaan.

Signalling Theory menjelaskan bahwa perusahaan akan memberikan sinyal kepada pihak luar, baik itu investor maupun masyarakat berupa informasi yang menunujukkan bahwa perusahaan tersebut memiliki kinerja yang lebih baik dibandingkan perusahaan lain. Rustariani (2010) menyatakan bahwa perusahaan akan mengungkapkan suatu informasi jika informasi tersebut dapat meningkatkan nilai perusahaan. CSR dalam hal ini diharapkan dapat memberikan sinyal positif kepada para stakeholder-nya. Sinyal positif diharapkan dapat membantu perusahaan membangun image perusahaan yang positif, sehingga berdampak pada kinerja pasar perusahaan yang tercermin dalam harga pasar saham dari perusahaan tersebut, yang berarti juga meningkatkan nilai perusahaan (Kusumadilaga, 2010). Penelitian yang mengaitkan CSR dengan nilai perusahaan diungkapkan oleh Murwaningsari (2009), Rustariani (2010) serta Harjoto dan Jo (2011) yang mendukung hipotesa yang menyatakan bahwa tingkat pengungkapan informasi CSR dalam laporan tahunan perusahaan berpengaruh positif pada nilai perusahaan.

$\mathrm{H}_{7} \quad$ : CSR berpengaruh positif pada nilai perusahaan.

Rumusan hipotesis sebelumnya sudah menjelaskan bagaimana hubungan antar variabel secara parsial, yaitu bagaimana masing-masing pengaruh profitabilitas, leverage dan modal kerja pada CSR dan juga pengaruhnya pada nilai perusahaan. 
Hipotesis yang disusun tersebut menunjukkan bahwa hubungan antara variabel berbeda-beda, ada yang berpengaruh positif maupun negatif. Maka dapat ditarik rumusan hipotesis sebagai berikut.

$\mathrm{H}_{8 \mathrm{a}}$ : Profitabilitas berpengaruh pada nilai perusahaan melauli CSR.

$\mathrm{H}_{8 \mathrm{~b}}$ : Leverage berpengaruh pada nilai perusahaan melauli CSR.

$\mathrm{H}_{8 c}$ : Modal kerja berpengaruh pada nilai perusahaan melauli CSR.

\section{METODE PENELITIAN}

Desain penelitian yang digunakan dalam penelitian ini adalah pendekatan kuantitatif asosiatif tipe kausalitas. Metode penelitian kuantitatif dapat diartikan sebagai metode penelitian berdasarkan pada fakta dan digunakan untuk meneliti suatu populasi atau sampel tertentu. Pendekatan Kuantitatif yang berbentuk asosiatif dengan tipe kausalitas merupakan jenis penelitian yang menjelaskan pengaruh variabel independen terhadap variabel dependen (Sugiyono, 2014).

Variabel yang diteliti dalam penelitian ini antara lain profitabilitas $\left(\mathrm{X}_{1}\right)$, leverage $\left(\mathrm{X}_{2}\right)$, modal kerja $\left(\mathrm{X}_{3}\right)$, nilai perusahaan $(\mathrm{Y})$ sebagai variabel dependen, dan CSR (M) sebagai variabel intervening. Nilai perusahaan merupakan persepsi investor terhadap tingkat keberhasilan perusahaan dalam mengelola sumber daya yang tercerrnin pada harga saham (Sujoko dan Soebiantoro, 2007). Corporate Social Responsibility (CSR) adalah komitmen bisnis untuk memberikan kontribusi bagi pembangunan ekonomi berkelanjutan, melalui kerjasama dengan para karyawan serta perwakilan mereka, komunitas setempat maupun masyarakat umum untuk meningkatkan kualitas kehidupan dengan cara yang bermanfaat baik bagi bisnis sendiri maupun untuk pembangunan. 
ISSN: 2302-8556

E-Jurnal Akuntansi Universitas Udayana

Vol.23.3.Juli (2018): 1-29

Penelitian ini dilakukan pada perusahaan consumer goods yang terdaftar di BEI tahun 2013-2015, dengan mengunduh laporan tahunan (annual report) yang diakses melalui www.idx.co.id. Objek dalam penelitian ini adalah nilai perusahaan dalam laporan tahunan (annual report) yang dapat diakses melalui www.idx.co.id. Jenis data yang digunakan dalam penelitian ini adalah data kuantitatif. Data kuantitatif merupakan data berupa angka-angka yang dapat dihitung dalam satuan hitung (Sugiyono, 2014:12). Sumber data yang digunakan dalam penelitian ini diperoleh dari website BEI (Bursa Efek Indonesia) yaitu www.idx.co.id

Sumber data yang digunakan dalam penelitian ini yaitu sumber data sekunder. Sumber data sekunder merupakan sumber yang memberikan data secara tidak langsung, seperti melalui orang lain atau dokumen (Sugiyono, 2014). Data sekunder dalam penelitian ini diperoleh dari laporan tahunan (annual report) yang dapat diakses melalui www.idx.co.id. Populasi pada penelitian ini adalah seluruh perusahaan consumer goods yang terdaftar di Bursa Efek Indonesia. Populasi pada penelitian ini merupakan wilayah generalisasi yang terdiri atas objek dan subjek yang mempunyai kualitas tertentu yang ditetapkan untuk dipelajari oleh peneliti (Sugiyono, 2014: 115).

Sampel pada penelitian ini diambil menggunakan metode non probability sampling dengan teknik purposive sampling. Teknik purposive sampling adalah penentuan sampel dengan pertimbangan tertentu (Sugioyono, 2014:122). Pada 
penelitian ini metode yang digunakan adalah metode observasi nonpartisipan. Metode observasi nonpartisipan yaitu teknik pengumpulan data dengan cara observasi atau pengamatan dimana peneliti tidak terlibat langsung, tetapi hanya sebagai pengamat independen (Sugiyono, 2014).

Uji statistik deskriptif adalah statistik yang digunakan untuk menganalisis data dengan cara mendeskripsikan atau menggambarkan data yang telah terkumpul sebagaima adanya, tanpa bermaksud membuat kesimpulan yang berlaku umum atau generalisasi (Sugiyono, 2014:206). Statistik deskriptif dalam penelitian ini disajikan untuk memberikan informasi mengenai profitabilitas, leverage, modal kerja, Corporate Social Responsibility, dan nilai perusahaan. Semua variabel tersebut dideskripsikan dengan nilai minimum, maksimum, rata-rata, dan simpangan baku (standar deviasi). Untuk keperluan analisis, variabel yang dioperasikan harus memenuhi persyaratan sehingga tidak menimbulkan hasil yang bias dalam pengujian. Adapun uji asumsi klasik yang digunakan dalam penelitian ini antara lain uji normalitas, uji multikolinearitas, uji autokorelasi dan uji heterokedastisitas.

Analisis jalur bertujuan untuk menganalisis pola hubungan antar variabel dengan tujuan untuk mengetahui pengaruh tidak langsung seperangkat variabel bebas terhadap variabel terikat yang dimediasi oleh variabel intervening. Analisis jalur ini sebenarnya merupakan perluasan dari analisis regresi linier berganda, untuk menaksir hubungan kausalitas antar variabel yang berjenjang berdasarkan teori (Utama, 2012: 156). 
ISSN: 2302-8556

E-Jurnal Akuntansi Universitas Udayana

Vol.23.3.Juli (2018): 1-29

\section{HASIL DAN PEMBAHASAN}

Berdasarkan Tabel 1 dapat dijelaskan hasilnya yaitu variabel profitabilitas memiliki nilai minimum sebesar -0,2080; nilai maksimum sebesar 0,3100; mean sebesar 0,076428 dan standar deviasi sebesar 0,0982036. Ini berarti bahwa terjadi perbedaan nilai ROA yang diteliti terhadap nilai rata-ratanya sebesar 0,0982036 . Variabel leverage memiliki nilai minimum sebesar 0,1406; nilai maksimum sebesar 1,2487; mean sebesar 0,422613 dan standar deviasi sebesar 0,1999064. Ini berarti bahwa terjadi perbedaan nilai DAR yang diteliti terhadap nilai rata-ratanya sebesar 0,1999064 .

\section{Tabel 1}

Hasil Statistik Deskriptif

\begin{tabular}{lrrrrr}
\hline & N & Minimum & Maximum & Mean & \multicolumn{1}{c}{$\begin{array}{c}\text { Std. } \\
\text { Deviation }\end{array}$} \\
\hline ROA & 60 & $-0,2080$ & 0,3100 & 0,076428 & 0,0982036 \\
DAR & 60 & 0,1406 & 1,2487 & 0,422613 & 0,1999064 \\
MK & 60 & 23,9886 & 30,5501 & 27,121898 & 1,7949672 \\
PBV & 60 & $-2,9390$ & 8,9941 & 2,515247 & 2,3349393 \\
CSR & 60 & 0,0476 & 0,5714 & 0,197417 & 0,1369412 \\
Valid N (listwise) & 60 & & & & \\
\hline \multicolumn{5}{l}{ Sumber: data diolah, 2017. }
\end{tabular}

Variabel modal kerja memiliki nilai minimum sebesar 23,9886; nilai maksimum sebesar 30,5501; mean sebesar 27,121898 dan standar deviasi sebesar 1,7949672. Ini berarti bahwa terjadi perbedaan nilai modal kerja yang diteliti terhadap nilai rata-ratanya sebesar 1,7949672 . Variabel nilai perusahaan memiliki nilai minimum sebesar -2,9390; nilai maksimum sebesar 8,9941; mean sebesar 2,515247 dan standar deviasi sebesar 2,3349393. Ini berarti bahwa terjadi perbedaan 
nilai PBV yang diteliti terhadap nilai rata-ratanya sebesar 2,3349393. Variabel modal kerja memiliki nilai minimum sebesar 0,0476; nilai maksimum sebesar 0,5714; mean sebesar 0,197417 dan standar deviasi sebesar 0,1369412. Ini berarti bahwa terjadi perbedaan nilai CSR yang diteliti terhadap nilai rata-ratanya sebesar 0,1369412.

Analisis regresi sangat memerlukan bagian asumsi agar model dapat digunakan sebagai alat prediksi baik. Selanjutnya, dilakukan uji asumsi classical linear regression model (uji asumsi klasik). Nilai Kolmogorov-Smirnov Z sebesar 1,154 dan tidak signifikan pada 0,05 (karena $\mathrm{P}=0,139>0,05$ ). Jadi dapat disimpulkan bahwa residual berdistribusi normal. Nilai Tolerance dan VIF, dimana diperlihatkan bahwa tidak terdapat nilai Tolerance yang kurang dari 0,1 ataupun nilai VIF yang lebih tinggi dari 10. Oleh karena itu berdasarkan nilai Tolerance dan VIF pada model analisis struktur 1 tersebut tidak ditemukan adanya gejala multikolinearitas. nilai Tolerance yang kurang dari 0,1 ataupun nilai VIF yang lebih tinggi dari 10. Oleh karena itu berdasarkan nilai Tolerance dan VIF pada model analisis struktur 2 tersebut tidak ditemukan adanya gejala multikolinearitas.

Nilai Durbin Watson sebesar 2,074. Nilai DW menurut tabel dengan $n=60$ dan $k=3$ didapat nilai $\mathrm{dL}=1,4797$ dan nilai $\mathrm{dU}=1,6889$. Oleh karena nilai $\mathrm{dU}<\mathrm{DW}<3-\mathrm{dU}$ $(1,6889<2,074<1,3111)$, maka dapat disimpulkan tidak terdapat autokorelasi antar residual. Nilai Durbin Watson sebesar 1,774. Nilai DW menurut tabel dengan $n=60$ dan $k=3$ didapat nilai $\mathrm{dL}=1,4797$ dan nilai $\mathrm{dU}=1,6889$. Oleh karena nilai $\mathrm{dU}<\mathrm{DW}<3-\mathrm{dU} \quad(1,6889<1,774<1,3111)$, maka dapat disimpulkan tidak terdapat autokorelasi antar residual. 
ISSN: 2302-8556

E-Jurnal Akuntansi Universitas Udayana

Vol.23.3.Juli (2018): 1-29

Hasil nilai signifikansi profitabilitas (ROA) sebesar 0,345 ; leverage (DAR) sebesar 0,677; dan modal kerja sebesar 0,765. Hasil uji tersebut memiliki nilai yang lebih besar dari $\alpha=0,05$. Oleh karena itu, dapat disimpulkan bahwa tidak terjadi heteroskedastisitas. Hasil nilai signifikansi profitabilitas (ROA) sebesar 0,226; leverage (DAR) sebesar 0,513; modal kerja sebesar 0,618; dan CSR sebesar 0,482. Hasil uji tersebut memiliki nilai yang lebih besar dari $\alpha=0,05$. Oleh karena itu, dapat disimpulkan bahwa tidak terjadi heteroskedastisitas.

Pengujian data dalam penelitian ini menggunakan teknik analisis jalur (Path Analysis), dimana analisis jalur adalah perluasan dari analisis regresi linear berganda untuk menguji hubungan kausalitas antara 2 atau lebih variabel. Analisis jalur pada penelitian ini diolah dengan bantuan software SPSS 17.0 for Windows dengan hasil yang dapat dilihat pada Tabel 2 dan 3 berikut.

Tabel 2.

Hasil Analisis Jalur Struktur 1

\begin{tabular}{|c|c|c|c|c|c|c|}
\hline \multirow[t]{2}{*}{ Model } & & \multicolumn{2}{|c|}{ Unstandardized Coefficients } & \multirow{2}{*}{$\begin{array}{c}\begin{array}{c}\text { Standardized } \\
\text { Coefficients }\end{array} \\
\text { Beta }\end{array}$} & \multirow[t]{2}{*}{$\mathbf{T}$} & \multirow[t]{2}{*}{ Sig. } \\
\hline & & B & Std. Error & & & \\
\hline \multirow[b]{9}{*}{ a Den } & (Constant) & $-0,837$ & 0,250 & & $-3,355$ & 0,001 \\
\hline & ROA & $-0,100$ & 0,223 & $-0,071$ & $-0,447$ & 0,657 \\
\hline & DAR & $-0,020$ & 0,105 & $-0,030$ & $-0,194$ & 0,847 \\
\hline & MK & 0,039 & 0,010 & 0,508 & 4,016 & 0,000 \\
\hline & R Square & & & & & 0,239 \\
\hline & Adjusted $\mathrm{R}^{2}$ & & & & & 0,199 \\
\hline & F Hitung & & & & & 5,876 \\
\hline & Sig F & & & & & 0,001 \\
\hline & ndent Variabl & CSR & & & & \\
\hline
\end{tabular}

$$
\mathrm{CSR}=-0,837-0,071 \mathrm{ROA}-0,030 \mathrm{DAR}+0,508 \mathrm{MK}
$$

Tabel 3.

Hasil Analisis Jalur Struktur 2 




$$
\mathrm{PBV}=-3,624+0,921 \mathrm{ROA}+0,239 \mathrm{DAR}+0,105 \mathrm{MK}-0,126 \mathrm{CSR}
$$

Hasil analisis regresi menunjukan bahwa profitabilitas secara statistik tidak berpengaruh pada CSR ( $\mathrm{H}_{1}$ ditolak). Hubungan pihak agen dengan prinsipal harus memiliki kualitas informasi yang sama, dengan tujuan memaksimalkan kinerja dan citra perusahaan yang dipandang baik dari pihak eksternal. Perusahaan yang menghasilkan laba yang tinggi atau pun tidak menghasilkan laba juga dapat mengungkapkan CSR untuk kepentingan meningkatkan citra perusahaan, dimana citra perusahaan tersebut tetap dipandang baik oleh pihak eksternal dan investor tetap tertarik menanam modalnya di perusahaan tersebut. Wijaya (2012) membuktikan hasil yang mendukung yaitu profitabilitas tidak berpengaruh pada CSR. Hal ini disebabkan ketika suatu perusahaan mempunyai tingkat laba rendah, perusahaan akan berharap investor untuk membaca good news menganai kinerja perusahaan. Sembiring (2005) dan Nur (2012) dalam penelitiannya juga membuktikan hal yang sejalan bahwa profitabilitas tidak berpengaruh pada CSR. 
ISSN: 2302-8556

E-Jurnal Akuntansi Universitas Udayana

Vol.23.3.Juli (2018): 1-29

Hasil analisis regresi menunjukan bahwa leverage secara statistik tidak berpengaruh pada CSR ( $\mathrm{H}_{2}$ ditolak). Teori keagenan menjelaskan hubungan antara agen dan prisipal harus dilandasi oleh sebuah kontrak yang efisien. Agen dalam menjalankan kegiatan perusahaan memerlukan tambahan biaya agar dapat memenuhi operasional perusahaan. Hutang perusahaan yang tinggi maupun rendah dibandingkan dengan aset perusahaan tersebut, tidak berdampak pada tingkat pengungkapan CSR sebuah perusahaan. Penelitian yang dilakukan oleh Wijaya (2012) juga membuktikan bahwa leverage tidak berpengaruh pada tingkat pengungkapan CSR, karena sudah terjadi hubungan yang baik antara perusahaan dan debtholders, yang mengakibatkan debtholders tidak terlalu memperhatikan rasio leverage perusahaan. Sembiring (2005), Anggreini (2006), dan Fahrizqi (2010) dalam penelitiannya membuktikan tidak adanya hubungan antara rasio leverage terhadap CSR.

Hasil analisis regresi menunjukan bahwa modal kerja secara statistik berpengaruh positif pada CSR $\left(\mathrm{H}_{3}\right.$ diterima). Tujuan dari teori sinyal adalah untuk mengurangi adanya asimetris informasi dari perusahaan kepada pihak eksternal. Pengungkapan CSR adalah salah satu cara dari perusahaan untuk menyampaikan informasi tersebut. Perusahaan yang memiliki dan mampu mengelola modal kerja yang baik maka dapat menutupi kebutuhan jangka pendek perusahaan dengan lancar, sehingga perusahaan kemungkinan dapat mengungkapkan CSR dari hasil usaha atau labanya. Gatsi dan Ameyibor (2016) menyatakan bahwa modal kerja memiliki hubungan positif terhadap CSR. Ofori, Nyuur, dan Darko (2014) pada penelitiannya menyatakan adanya hubungan positif modal kerja terhadap pengungkapan CSR. Goss 
dan Roberts (2009) menyatakan sebaliknya bahwa tidak ada hubungan antara modal kerja dan CSR. Modal kerja yang cukup dan efektif akan meningkatkan nilai perusahaan, sehingga nilai perusahaan yang baik terkait dengan adanya pengungkapan CSR akan memberikan sinyal yang positif kepada pihak eksternal.

Hasil analisis regresi menunjukan bahwa profitabilitas secara statistik berpengaruh positif pada nilai perusahaan $\left(\mathrm{H}_{4}\right.$ diterima). Teori sinyal menjelaskan bagaimana seharusnya perusahaan menyampaikan sinyal yang baik kepada investor dalam menjelaskan keadaan perusahaan. Profitabilitas atau Return On Asset (ROA) merupakan rasio yang paling baik dalam memprediksikan penumbuhan laba. Susianti (2013) menyatakan nilai ROA yang tinggi merupakan sinyal positif bagi investor bahwa perusahaan dalam kondisi yang menguntungkan. Hal ini menjadi daya tarik investor untuk memiliki saham perusahaan dan akan meningkatkan harga saham sehingga nilai perusahaan pun meningkat. Selain itu, diasumsikan bahwa profitabilitas menunjukkan tingkat keuntungan bersih yang mampu diraih oleh perusahaan saat menjalankan operasinya. Profitabilitas yang tinggi akan menarik minat investor untuk menanamkan modalnya di perusahaan, maka hal itu dapat meningkatkan nilai perusahaan. Hasil penelitian ini didukung oleh penelitian yang dilakukan oleh Ju Chen dan Yu Chen (2011) yang menunjukkan bahwa profitabilitas berpengaruh terhadap nilai perusahaan. Penelitian yang dilakukan oleh Irma (2014) dan Wahyudi (2012) juga memperkuat penelitian ini dengan hasil serupa yang menyatakan bahwa profitabilitas yang diproksikan dengan Return On Assets 
ISSN: 2302-8556

E-Jurnal Akuntansi Universitas Udayana

Vol.23.3.Juli (2018): 1-29

berpengaruh terhadap nilai perusahaan sehingga ketika laba perusahaan naik maka nilai perusahaan akan ikut naik.

Hasil analisis regresi menunjukan bahwa leverage secara statistik berpengaruh positif pada nilai perusahaan $\left(\mathrm{H}_{5}\right.$ ditolak). Struktur hutang atau leverage merupakan gambaran mengenai besar atau kecilnya pemakaian hutang oleh suatu perusahaan yang digunakan untuk membiayai aktivitas operasionalnya. Tingkat leverage yang tinggi dapat meningkatkan nilai perusahaan karena perusahaan dapat menggunakan hutang untuk memenuhi kegiatan operasional perusahaan yang nantinya diharapkan menghasilkan laba atau nilai yang maksimal. Analisa (2011) membuktikan hasil penelitian yang mendukung bahwa rasio leverage berpengaruh positif terhadap nilai perusahaan. Hardiyanti (2012) membuktikan hasil yang sejalan yaitu leverage berpengaruh positif terhadap nilai perusahaan.

Hasil analisis regresi menunjukan bahwa modal kerja secara statistik tidak berpengaruh pada nilai perusahaan $\left(\mathrm{H}_{6}\right.$ ditolak). Teori keagenan menyatakan principal dalam hubungannya dengan agent dilandasi oleh sebuah kontrak. Kontrak tersebut mendelegasikan keinginan principal kepada agent, dimana agent menjalankan pendelegasian tersebut salah satunya adalah menjalankan operasional perusahaan. Banyak atau sedikitnya ketersediaan modal kerja yang dimiliki perusahaan tidak dapat meningkatkan atau pun menurunkan nilai perusahaan. Taufik (2013) membuktikan bahwa modal kerja tidak berpengaruh pada nilai perusahaan. Penelitian yang dilakukan oleh Warouw,dkk. (2016) membuktikan hubungan tidak signifikan variabel modal kerja terhadap nilai perusahaan. 
I G. N. Yoga Dimas Atmaja dan Ida Bagus Putra Astika. Pengaruh ...

Hasil analisis regresi menunjukan bahwa CSR secara statistik tidak berpengaruh pada nilai perusahaan $\left(\mathrm{H}_{7}\right.$ ditolak). Signalling Theory menjelaskan bahwa suatu perusahaan cenderung akan menyampaikan sinyal yang baik kepada pengguna laporan keuangan yang menunjukkan perusahaan tersebut memiliki kinerja yang lebih baik dibandingkan perusahaan lain. Tingkat pengungkapan CSR yang dilakukan perusahaan tidak dapat meningkatkan atau pun menurunkan nilai perusahaan tersebut. Hal ini diakibatkan oleh perusahaan yang tidak melakukan pengkomunikasian tanggung jawab sosial secara tepat sehingga belum ditangkap sebagai sesuatu yang perlu diperhatikan oleh pihak-pihak yang berkepentingan. Hasil penelitian ini sama dengan hasil penelitian yang dilakukan oleh Nurlela dan Islahudin (2008), Wahab dan Mulya (2012) yang membuktikan bahwa variabel CSR tidak berpengaruh secara signifikan terhadap nilai perusahaan.

Hasil uji hipotesis pada pengaruh tidak langsung variabel profitabilitas $\left(\mathrm{X}_{1}\right)$, leverage $\left(\mathrm{X}_{2}\right)$, dan modal kerja $\left(\mathrm{X}_{3}\right)$ pada nilai perusahaan $(\mathrm{Y})$ yang dimediasi oleh CSR (M), diperoleh nilai pengaruh tidak langsung (PTL) masing-masing variabel yaitu profitabilitas $\left(\mathrm{X}_{1}\right)$ sebesar 0,008 ; leverage $\left(\mathrm{X}_{2}\right)$ sebesar $-0,003$; dan modal kerja $\left(\mathrm{X}_{3}\right)$ sebesar 0,014. Hal ini menunjukkan bahwa nilai pengaruh langsung seluruh variabel lebih besar dari pengaruh tidak langsung, sehingga dapat disimpulkan bahwa CSR bukan merupakan variabel intervening atau mediasi antara variabel profitabilitas $\left(\mathrm{X}_{1}\right)$, leverage $\left(\mathrm{X}_{2}\right)$, dan modal kerja $\left(\mathrm{X}_{3}\right)$ pada nilai perusahaan $(\mathrm{Y})$.

Nilai sobel profitabilitas pada nilai perusahaan sebesar $0,357 \quad(<1,96)$ menunjukan hasil bahwa variabel mediator yakni CSR dinilai tidak memediasi 
ISSN: 2302-8556

E-Jurnal Akuntansi Universitas Udayana

Vol.23.3.Juli (2018): 1-29

hubungan antara profitabilitas $\left(\mathrm{X}_{1}\right)$ pada nilai perusahaan $(\mathrm{Y})\left(\mathrm{H}_{8 \mathrm{a}}\right.$ ditolak). Nilai sobel leverage pada nilai perusahaan sebesar $0,155(<1,96)$ menunjukan hasil bahwa variabel mediator yakni CSR dinilai tidak memediasi hubungan antara leverage $\left(\mathrm{X}_{2}\right)$ pada nilai perusahaan $(\mathrm{Y})\left(\mathrm{H}_{8 \mathrm{~b}}\right.$ ditolak). Nilai sobel modal kerja pada nilai perusahaan sebesar $-1,316(<1,96)$ menunjukan hasil bahwa variabel mediator yakni CSR dinilai tidak memediasi hubungan antara modal kerja $\left(\mathrm{X}_{3}\right)$ pada nilai perusahaan $(\mathrm{Y})\left(\mathrm{H}_{8 \mathrm{c}}\right.$ ditolak).

Hal ini berarti bahwa profitabilitas, leverage, dan modal kerja tidak dapat meningkatkan nilai perusahaan yang didukung oleh CSR dalam perusahaan. Pengungkapan CSR perlu dilakukan sebagai wujud tanggung jawab dan bentuk komunikasi perusahaan terhadap para stakeholder-nya mengenai kinerja dan kondisi perusahaan. CSR merupakan suatu hal yang dapat mempengaruhi karakterisitik perusahaan yang dapat berpengaruh juga terhadap nilai suatu perusahaan baik secara langsung maupun tidak langsung.

\section{SIMPULAN}

Berdasarkan pada hasil analisis data dan pembahasan yang telah dipaparkan sebelumnya, maka dapat ditarik kesimpulan sebagai berikut: Profitabilitas tidak berpengaruh pada CSR pada perusahaan consumer goods yang terdaftar di Bursa Efek Indonesia periode 2013-2015. Leverage tidak berpengaruh pada CSR pada perusahaan consumer goods yang terdaftar di Bursa Efek Indonesia periode 20132015. Modal Kerja berpengaruh positif pada CSR pada perusahaan consumer goods yang terdaftar di Bursa Efek Indonesia periode 2013-2015. Modal kerja yang cukup 
I G. N. Yoga Dimas Atmaja dan Ida Bagus Putra Astika. Pengaruh ...

akan meningkatkan kesempatan perusahaan dalam mengungkapkan CSR. Profitabilitas berpengaruh positif pada nilai perusahaan pada perusahaan consumer goods yang terdaftar di Bursa Efek Indonesia periode 2013-2015. Profitabilitas yang tinggi pada perusahaan dapat meningkatkan minat investor untuk menanamkan modalnya di perusahaan tersebut, sehingga dapat meningkatkan nilai perusahaan. Leverage berpengaruh positif pada nilai perusahaan pada perusahaan consumer goods yang terdaftar di Bursa Efek Indonesia periode 2013-2015. Modal kerja tidak berpengaruh pada nilai perusahaan pada perusahaan consumer goods yang terdaftar di Bursa Efek Indonesia periode 2013-2015. CSR tidak berpengaruh pada nilai perusahaan pada perusahaan consumer goods yang terdaftar di Bursa Efek Indonesia periode 2013-2015. Variabel mediator CSR dinilai tidak mampu memediasi hubungan antara profitabilitas pada nilai perusahaan pada perusahaan consumer goods yang terdaftar di Bursa Efek Indonesia periode 2013-2015. Variabel mediator CSR dinilai tidak mampu memediasi hubungan antara leverage pada nilai perusahaan pada perusahaan consumer goods yang terdaftar di Bursa Efek Indonesia periode 2013-2015. Variabel mediator CSR dinilai tidak mampu memediasi hubungan antara modal kerja pada nilai perusahaan pada perusahaan consumer goods yang terdaftar di Bursa Efek Indonesia periode 2013-2015.

Saran yang dapat diberikan berdasarkan hasil penelitian yang didapat adalah penelitian selanjutnya perlu mempertimbangkan sampel yang lebih luas, hal ini bertujuan agar cakupan hasil yang di dapat menjadi lebih luas. Perusahaan diharapkan tetap menerapkan CSR atau informasi tanggung jawab sosial sebagai keunggulan 
ISSN: 2302-8556

E-Jurnal Akuntansi Universitas Udayana

Vol.23.3.Juli (2018): 1-29

kompetitif perusahaan. Penelitian selanjutnya hendaknya mempertimbangkan

beberapa variabel lain seperti kepemilikan menejerial, kepemilikan asing, kebijakan

deviden dan lain sebagainya yang mungkin mempengaruhi nilai perusahaan.

\section{REFERENSI}

Anggraini, F.R. 2006. Pengungkapan Informasi Sosial dan Faktor-Faktor yang Memengaruhi Pengungkapan Informasi Sosial dalam Laporan Keuangan Tahunan (Studi Empiris pada Peusahaan-Perusahaan yang Terdaftar di Bursa Efek Jakarta). Simposium Nasional Akuntansi IX.

Arif, Wibowo. 2005. Pengantar Analysis Jalur (Path Analysis). Surabaya: Lembaga Penelitian Universitas Airlangga.

Astika, I.B. Putra. 2007. Perilaku Oportunistik Eksekutif dalam Pelaksanaan Program Opsi Saham Karyawan. Desertasi Program Magister Sain dan Doktor FE $U G M$.

Ayu, Rizqia, Dwita, Siti Aisjah, dan Sumiati. 2013. Effect of Managerial Ownership, Financial Leverage, Profitability, Firm Size, and Investment Opportunity on Dividend Policy and Firm Value. Research Journal of Finance and Accounting, 4 (11), ISSN: 2222-2847.

Brigham, F., dan J. Houston. 2001. Manajemen Keuangan, Edisi Kedelapan. Jakarta: Erlangga.

Brigham, F., dan J. Houston. 2006. Dasar-Dasar Manajemen Keuangan, alih bahasa Ali Akbar Yulianto, Buku satu, Edisi sepuluh, PT. Salemba Empat, Jakarta.

Chaundhry, Suman K., Das, Sanjay K., dan Sahoo, Prasantha K. 2011. Practices of Corporate Social Responsibility (CSR) in Banking Sector in India: An Assessment. Research Journal of Economics, Business and ICT, 4.

Eisenhardt, Kathleem. 1989. Agency Theory: An Assesment and Review. Academy of Management Review, 14: h:57-74..

Gatsi, J. Gartchie.,dan Ameyibor, Joseph. 2016. A Study of Corporate Social Responsibility and Working Capital: Evidence from the United Kingdom. IOSR Journal of Economics and Finance (IOSR-JEF) e-ISSN: 2321-5933, pISSN: 2321-5925. 7 (2): h:53-59. 
Goss, Allen., dan Roberts, Gordon S. 2009. The Impact of Corporate Social Responsibility on the Cost of Bank Loans.

Harjoto, Maretno A., and Jo, Hoje. 2011. Corporate Governance and CSR Nexus. Journal of Business Ethics (JBE) special issue.

Indraswari, Gusti Ayu D dan Ida Bagus P A. 2014. Pengaruh Profitabilitas, Ukuran Perusahaan, dan Kepemilikan Saham Publik Pada Pengungkapan CSR. EJurnal Akuntansi Universitas Udayana, 9 (3): h:816-828, ISSN: 2302-8556.

Indrawan, Danu Candra. 2011. Pengaruh Corporate Social Responsibility Terhadap Kinerja Perusahaan. Skripsi. Fakultas Ekonomi Universitas Diponegoro Semarang.

Irma, Ni Kadek. 2014. Pengaruh Kinerja pada Nilai Perusahaan dengan Corporate Social Responsibility Sebagai Variabel Pemoderasi. E-Jurnal Universitas Udayana. 7 (3), 2014.

Ju Chen, Li and Yu Chen, Shun. 2011. The Influence of Profitability on Firm Value with Capital Structure as The Mediator and Firm Size and Industry as Moderator. Investment Management and Financial Innovations. 8 (3).

Kasmir. 2011. Analisis Laporan Keuangan.Edisi 1. Jakarta: Rajawali Pers.

Kusumajaya. 2011. Pengaruh Struktur Modal dan Pertumbuhan Perusahaan Terhadap Profitabilitas dan Nilai Perusahaan pada Perusahaan Manufaktur di Bursa Efek Indonesia. 30 November, 2014. Universitas Udayana.

Lai, Limin. 2012. The Impact of Working Capital Management on Firm Value: Evidence from Airline Industry. Master Thesis.

Li-Ju, Chen and Shun-Yu, Chen. 2011. The Influence of Profitability on Firm Value with Capital Structure as the Mediator and Firm Size and Industry as Moderators. Journal Management and Financial Innovations, 8 (3).

Maria, Ni Luh. 2013. Pengaruh Kinerja Keuangan Terhadap Nilai Perusahaan dengan Pemoderasi Good Corporate Governance dan Corporate Social Responsibility. E-Journal Universitas Udayana. 3 (1).

Melia, Putri. 2008. Pengaruh Profabilitas dan Tata Kelola Manajeman Pada Nilai Perusahaan di Sektor Jasa. Jurnal Manajemen, 8 (3): h:45-77. 
ISSN: 2302-8556

E-Jurnal Akuntansi Universitas Udayana

Vol.23.3.Juli (2018): 1-29

Murwaningsari, E. 2009. Hubungan Corporate Governance, Corporate Social Responsibility dan Corporate Financial Performance dalam Satu Continuum. Jurnal Akuntansi dan Keuangan, 11 (1): h:30-41.

Nur, Marzully., dan Priantinah, Denies. 2012. Analisis Faktor-Faktor yang Memengaruhi Pengungkapan Corporate Social Responsibility di Indonesia (Studi Empiris pada Peusahaan Berkategori High Profil yang Listing di Bursa Efek Indonesia). Jurnal Nominal, 1 (1), Universitas Negeri Yogyakarta.

Nurjanah, Dwi Pratiwi., Suhadak, Suhadak., dan Kumadji, Srikandi. 2014. Pengaruh Modal Kerja dan Struktur Modal terhadap Profitabilitas dan Nilai Perusahaan (Studi pada Sektor Aneka Industri yang Terdaftar di BEI 2009-2012). EJournal Universitas Brawijaya, 8 (2).

Nurlela dan Islanhudin. 2008. Pengaruh Corporate Social Responsibility Terhadap Nilai Perusahaan dengan Prosentasi Kepemilikan Manajemen sebagai Variabel Moderating. Simposium Nasional Akuntansi XI.

Ofori, Daniel F., Nyuur, Richard B., dan Darko, Mildred D.S. 2014. Corporate Social Responsibility and Financial Performance: Fact or Fiction? A Look at Ghanaian Banks. AOSIS Open Journals.

Pebriana. 2012. Pengaruh Profitabilitas, Leverage, Umur Perusahaan, Komposisi Dewan Direksi Dan Kepemilikan Instusional Pada Pengungkapan Corporate Social Responsibility (CSR) Di Bursa Efek Indonesia.

Rustariani, Ni Wayan. 2010. Pengaruh Corporate Governance pada Hubungan Corporate Social Responsibility dan Nilai Perusahaan. Simposium Nasional Akuntansi XIII.

Sabri, T. Bahjat. 2012. The Impact of Working Capital on The Value of The Company in Light of Differing Size, Growth, and Debt. Business and Economic Horizonsi. 7.

Sartono, R. Agus. 2010. Manajemen Keuagan Teori dan Aplikasi Edisi 5. Yogyakarta: BPFE.

Sembiring, E.R. 2003. Kinerja Keuangan, Political Visibility, Ketergantungan pada Hutang, dan Pengungkapan Tanggung Jawab Sosial Perusahaan. Simposium Nasional Akuntansi VI. 
Sembiring, E.R. 2005. Kinerja Keuangan, Political Visibility, Ketergantungan pada Hutang, dan Pengungkapan Tanggung Jawab Sosial Perusahaan. Simposium Nasional Akuntansi VII.

Sugiyono. 2014. Metode Penelitian Bisnis. Bandung: Alfabeta

Sujoko., dan Soebiantoro, Ugy. 2007. Pengaruh Struktur Kepemilikan Saham, Leverage, Faktor Intern dan Faktor Ekstern Terhadap Nilai Perusahaan (Studi Empirik pada Perusahaan Manufaktur dan Non Manufaktur di Bursa Efek Jakarta). Jurnal Manajemen dan Kewirausahaan, 9 (1): h:41-48.

Sukamulja, Sukmawati. 2004. Good Corporate Governance di Sektor Keuangan: Dampak Good Corporate Governance terhadap Kinerja Keuangan. 8 (1): h:125

Sukartha, Made. 2007. Pengaruh Manajemen Laba, Kepemilikan Manajerial dan Ukuran Perusahaan pada Kesejahteraan Pemegang Saham Perusahaan Target Akuisisi. Jurnal Riset Akuntansi Indonesia, 10 (3): h:243- 267.

Susanto, Sherly., dan Yulius Jogi Christiawan. 2016. Pengaruh Earning Management terhadap Firm Value. Business Accounting Review. 4 (1)

Susianti, Ni Luh. 2013. Pengaruh Kinerja Keuangan Terhadap Nilai Perusahaan dengan Pemoderasi Good Corporate Governance dan Corporate Social Responsibility. E-Journal Universitas Udayana, 3 (1): h:73-91.

Susilawati, Christine Dwi Karya. 2012. Analisis Perbandingan Pengaruh Likuiditas, Solvabilitas dan Profitabilitas terhadap Harga Saham pada Perusahaan LQ45. Jurnal Akuntansi. 4 (2), November 2012.

Taufik. 2013. Manajemen Modal Kerja, Profitabilitas, dan Nilai Perusahaan Sektor Manufaktur di PT Bursa Efek Indonesia. Jurnal Manajemen dan Bisnis Sriwijaya, (11) 4.

Utama, Made Suyana. 2012. Aplikasi Analisis Kualitatif. Edisi Keenam. Denpasar: Fakultas Ekonomi Universitas Udayana.

Utami, Sri., dan Sawitri Dwi Prastiti. 2011. Pengaruh Karakteristik Perusahaan terhadap Social Disclosure. Jurnal Ekonomi Bisnis, 16 (1): h:63-69.

Wahab, Abdul., Mulya, Anissa Amalia. 2012. Analisis Pengaruh Pengungkapan CSR, Kepemilikan Institusional, dan Ukuran Perusahaan Terhadap Nilai Perusahaan. Jurnal. Fakultas Ekonomi Universitas Budi Luhur. 
ISSN: 2302-8556

E-Jurnal Akuntansi Universitas Udayana

Vol.23.3.Juli (2018): 1-29

Warouw, Christiana., Nangoy, Sintje., Saerang, Ivonne S. 2016. Pengaruh Perputaran Modal Kerja dan Profitabilitas Terhadap Nilai Perusahaan pada Perusahaan Farmasi di Bursa Efek Indonesia. Jurnal Berkala Ilmiah Efisiensi, (16) 2.

Wijaya, Maria. 2012. Faktor-faktor yang Mempengaruhi Pengungkapan Tanggung Jawab Sosial pada Perusahaan Manufaktur yang Terdaftar di Bursa Efek Indonesia. Jurnal Ilmiah Mahasiswa Akuntansi, 1 (1): h: 29. 